\title{
Sustainability and Pastoral Livelihoods: Lessons from East African Maasai and Mongolia
}

\author{
Elliot Fratkin and Robin Mearns
}

\begin{abstract}
"Ststainable development" currently has a firm grip on the lexicon of development agencies from the World Bank to small nongovernmental organizations, but it offers little practical guidance for tackling diverse problems in specific places. The concept is of particular importance to pastoral populations throughout the world--those people dependent on livestock raising in arid or semiarid lands whose survival depends on their ability physically and politically to maintain access to their pastures. This paper compares two pastoralist populations-East African Maasai and pastoralists of Mongolia to discuss recent changes in the pastoral way of life and to describe what sustainability has meant in the past and what sustainability needs to mean in the future for pastoralist populations.
\end{abstract}

Key words: pastoralism, risk management, commons, Kenya, Tanzania, Inner Asia, Khalkh

$\mathrm{P}$ astoralist populations are facing more pressures to their waly of life than ever before. Population growth; loss of pastureland to private farms, ranches, game parks, and urban areas; increased commoditization and rising inequality within the livestock economy; out-migration of poor pastoralists; and periodic dislocations brought about by drought, famine, and civil war are collectively threatening a way of life that has proved in the past to be a highly adaptive

Elliot Fratkin is a professor of anthropology at Smith College Northampton, Massachusetts (e-mail: efratkin@smith.edu). Since 1974, he has conducted fieldwork among Ariaal, Rendille, and Samburu pastoralists of northern Kenya, focusing on the study of pastoral society and ecology, health, and social change. He has recently been a consultant on the World Bank Inspection Panel investigation of the Chad Cameroon Oil Pipeline Project. Elliot Fratkin's publications include Surviving Drought and Development in Kenya's Arid Lands (Westview Press, 1991), Ariaal Pastoralists of Kenya (2nd ed, Allyn and Bacon, 2003), African Pastoralist Systems (Lynne Rienne; 1994, coedited with Kathleen Galvin and Eric Abella Roth), and Cultural Anthropology (Allyn and Bacon, 2003, with Daniel G. Bates).

Robin Mearns is a senior natural resource management specialist in the East Asia and Pacific Region of the World Bank, and chair of the World Bank's Natural Resource Management Thematic Group (e-mail: mearns@worldbank.org). Based in Washington, D.C., his current operational responsibilities are in Mongolia (where he is rural sector coordinator) and Vietnam, with additional work in China and Indonesia. Prior to joining the World Bank in 1997, he held research and teaching positions at the Institute of Development Studies, University of Sussex, and the International Institute for Environment and Development, London. His publications include: The Lie of the Land: Challenging Received Wisdom on the African Environment (Jumes Currey, 1996, coedited with M. Leach), Beyond the Woodfuel Crisis: People, Land and Trees in Africa (Earthscan, 1988, with G. Leach), and numerous articles on institutional aspects of natural resource management in Africa and Asia. food production system in arid lands. Although the driving forces vary widely from region to region, virtually all of these trends result in declining mobility of livestock, which places in jeopardy the sustainability of both rangeland resources and pastoral livelihoods.

"Sustainable development" now has a firm grip on the lexicon of development agencies from the World Bank to small nongovernmental organizations, but it offers little practical guidance for tackling diverse problems in specific places. Local economies and livelihood systems throughout the world are coming under severe stress, particularly where agricultural yields have failed to keep pace with increasing demand. Until quite recently, Africa could feed itself, but today the majority of African countries import food from abroad (FAO 1994). Civil strife has led to profound disruption, death, and migration; there are more than enough examples from Angola, Burundi, Congo, Ethiopia, Liberia, Rwanda, Sierra Leone, Somalia, and Sudan, to name a few. The situation is not much better in Asia or Latin America, particularly where highly inequitable patterns of control over land and other key resources in export-driven economies have forced poor farmers to relocate to less productive regions or give way to urban and industrial growth.

This paper draws from our experiences in East Africa and Mongolia to discuss recent changes in the pastoral way of life, what sustainability has meant for these pastoral populations, and what sustainability needs to mean in the future. Pastoralists are people whose livelihood depends mainly on the raising of domestic animals-including cattle, camels, goats, sheep, yaks, horses, and donkeys-for milk, meat, wool, hides, transport, and trade.

Pastoralists occupy savannas, arid deserts, and high plateaus where rain-fed agriculture is precarious. They include 
well-known populations such as Tuareg, Fulani (or Fulbe, Peul), Somali, and Maasai in Africa; Bedouin, Baluch, Basseri, and Turkmen in the Middle East; and Kazakh, Mongols, and Tibetan Drokba in Asia (Barfield 1993). Pastoralists typically occupy large tracts of communally shared land and utilize kinship ties for mutual herding and defense. Their herds are often large, in poor condition, but hardy enough to survive periodic drought and sparse vegetation. Many pastoralists practice some agriculture; they may also supplement their pastoral diets with wild plants, game, fish, grains, and other food commodities purchased by the sale or trade of livestock, milk products, wool and other fibers, and hides. Some pastoral societies engage in longdistance trade, such as the Tuareg of the western Sahara, while others, such as the Maasai, practice localized livestock keeping in semipermanent settlements.

\section{Sustainable Development}

"Sustainability" became the watchword for development in the $1990 \mathrm{~s}$, precisely because it is a multifaceted concept, having different meanings for different players in the international development arena. To anthropologists, cultural ecologists, and human rights advocates, sustainability means the ability of a people to preserve and defend its way of life. For pastoralists in particular, this means maintaining livestock productivity, defending their rights and access to water and grazing resources, and ensuring political and economic security. Anthropologists and applied ecologists have demonstrated through numerous studies the rationality of pastoral strategies, including herd flexibility, diversity, and mobility, to ensure survival of human and animal populations in arid lands (Dahl and Hjort 1976; Dyson-Hudson and McCabe 1985; Behnke, Scoones, and Kerven 1993; Behnke 1994; Swallow 1994; Scoones 1995; Niamir-Fuller 1999).

For environmentalists, usually from northern countries, sustainability refers to the need to protect the earth's natural resources against further degradation. While some groups such as Greenpeace target industrial countries for their plundering of oil reserves, rainforests, and ocean fisheries, other groups including World Watch, Sierra Club, and World Conservation Union target human population growth and increased consumption as the main causes of resource depletion and degradation, particularly in the developing world. They often blame poor rural producers for what are perceived to be unsound practices including slash and burn cultivation, overgrazing, and deforestation for fuel wood. In response, they propose strategies they believe will reduce human population pressure on wildlife and other forms of biodiversity, such as removing indigenous peoples from endangered habitats through the creation of national parks and reserves (Leach and Mearns 1996).

By far the largest and most powerful players in the search for sustainability are the international development agencies, particularly the World Bank and bilateral donors including the United States Agency for International Development
(USAID). While the initial push for sustainable development may have come from environmental activists, the World Bank has embraced the multifaceted concept of sustainability as a framework to guide the search for operational strategies to reduce poverty (World Bank 1997, 2002, 2003). Lessons from experience confirm the wisdom of continuing to emphasize economic growth through macroeconomic stability, but they also suggest it is just as important to ensure that the benefits of growth are widely shared. This means addressing incquities in access to land, water, and economic opportunities, and points to the value of investments in human capital (e.g., health care and education) and in social capital (institutions of various kinds), which can help to prevent further decline in natural capital (natural resources, environmental quality) as well as reduce poverty and enhance people's basic capabilities (Serageldin 1996).

Critics ask, how can development that is export orientated and private sector led be truly "sustainable" if it relies on the incentives of private, profit-making ventures who will exploit resources and labor as cheaply as possible, with little regard for conserving for the future? (James 1996:71). Major petrochemical corporations are now among the loudest champions of sustainable development, not least because clean technology makes good business sense. Clouded by ideological differences, the sustainability debate will never be resolved at a level of abstraction divorced from the particular. What is certain is that sound policies and credible institutions for governance are vital to achieving sustainable development, however it is defined; including enforcable policies for regulating the private sector:

Development policy toward pastoralism has conventionally upheld a worldview shared by many national governments that pastoralists are irrational, wasteful, and shortsighted. This view is owed in no small part to Garret Hardin's tragedy-of-the-commons thesis, which became a metaphor for the state of environmental degradation worldwide:

\footnotetext{
The tragedy of the commons develops in this way. Picture a pasture open to all. It is to be expected that each herdsman will try to keep as many cattle as possible on the commons... As a rational being, each herdsman seeks to maximize his gain... The rational herdsman concludes that the only sensible course for him to pursue is to add another animal... and another; and another... But this is the conclusion reached by each and every rational herdsman sharing a commons. Therein is the tragedy. Each man is locked into a system which compels him to increase his herd without limit-in a world that is limited. Ruin is the destination towards which all men rush, each pursuing his own interest in a society that believes in the freedom of the commons. Freedom in a commons brings ruin to all (Hardin 1968: 1244).
}

The tragedy thesis became part of the conventional wisdom among environmentalists and within development policy. Although based on a fundamental confusion of common property with open access, the commons argument has been marshaled consistently to buttress the conviction that 
the world's deserts are "on the march" despite an absence of reliable empirical evidence to support that view (Fratkin 1997; Leach and Mearns 1996; Peters 1994). "Pastoral mismanagement" was seen as a leading factor contributing to "desertification," commonly understood to be a process of increasing desiccation in arid lands. Following the Sahelian drought of the early 1970s, the United Nations sponsored a Conference on Desertification in 1976 in Nairobi and established a "desertification branch" at the newly formed United Nations Environment Programme (UNEP). Solutions were proposed to limit or dismantle common property regimes (UNCOD 1977; Lamprey 1976; see Little 1994 and Swift 1996 for a more thorough discussion).

Hardin's thesis also provided a rationalization for livestock development projects between the 1960s and the 1980s that called for sweeping privatization of land and commercialization of livestock production. Development planners and agronomists agreed that a major problem in Africa was one of increasing livestock productivity to feed Africa's growing population. They saw the problem not so much as improving livestock productivity (through capital investments in water points, disease control, or range improvement, which had been tried without success in the colonial and postcolonial period in Africa), but one of limiting the size of herds on rangeland, which could best be achieved by enhancing livestock marketing, based on the Western model of the individually owned commercial ranch (Simpson and Evangelou 1984).

A strong counterargument has emerged in recent years grounded in a rich body of interdisciplinary research on common property regimes undertaken by anthropologists, political scientists, geographers, and economists that exposed the fundamental flaw in Hardin's argument (e.g., Bromley and Cernea 1989; Ostrom 1990). This body of research demonstrates that overexploitation is the result of an absence of effectively enforced rules for the management of common property, not of the presence of such arrangements: the trag edy of the commons is in fact a tragedy of open access. While some development planners and many national governments may be uncomfortable (for a wide variety of reasons) with traditional forms of collective land tenure, which they feel lack defined rules about how resources are used, customary tenure systems are often quite specific about who may or may not use grazing and water resources, how, and at what times.

Until recently, development policy toward pastoral regions held the following views in common: 1) most of the world's rangelands are suffering from degradation or desertification; 2) in most cases it is caused by overgrazing by domestic animals, which in turn is caused by an increase in the number of animals; 3 ) the technology is available to combat desertification, but is not applied because the traditional economic and social systems of pastoralists, and especially their systems of communal land tenure, militate against this; 4) the solution involves privatized tenure, such as commercial ranches or grazing blocks, where pasture use follows scientific advice about stocking levels and grazing rotation, implemented through a centralized bureaucratic organization (Sandford 1983:11-19). Informed by these preconceptions, large-scale assistance was provided by the World Bank and bilateral agencies between the $1960 \mathrm{~s}$ and $1980 \mathrm{~s}$ as fixed-term interventions, usually of highly capitalized infrastructural inputs including roads, slaughterhouses, railway transport, mechanized bore holes, dipping facilities, and feedlots, planned by outside technical experts for implementation by national government officers.

These government interventions have often been negative and frequently disastrous. As Swift (1991:34) writes:

\begin{abstract}
The record of this type of policy in Africa has been dismal, as any review of livestock projects shows. Land degradation, where it is taking place, has not been halted and has sometimes increased, livestock productivity has not grown although economic inequality has, and vulnerability to food insecurity and loss of tenure rights has increased. Faced with the failure of their policies, many major donors have stopped investing in livestock projects, and some now argue for a policy of benign neglect towards the dry areas on the grounds that little can be done there. During this same period, anthropologists and others have documented the rich array of customary institutions regulating resource use in African pastoral societies. However, there have been few attempts to base modern policies of resource conservation and management on customary ways of doing things. There are clearly many difficulties in doing this, but the failure of alternative policies suggest at least that this option should be tried.
\end{abstract}

Development policies aimed at pastoralists have undergone major transformations in recent years, although the effects have yet to be realized on the ground to any significant scale (Gilles and de Haan 1994; Pratt, LeGall, and de Haan 1997; de Haan et al. 2001). The "new" approach to pastoral development rests on a major reconsideration of dryland ecology and of what it means to derive livelihoods from environments that are intrinsically at disequilibrium; it aims wherever possible to build on customary institutions (Behnke, Scoones, and Kerven 1993; Behnke 1994; Scoones 1995; Swift 1996; Mearns 1997a, 1997b; Roe, Huntsinger, and Labnow 1998). While several programs encourage mixed farming with animal husbandry, the heart of the new approach is the recognition that sustainability in pastoral production systems demands livestock mobility, and that land tenure policy, rural infrastructure, and social service provision, including access to markets and appropriate banking facilities among other policies, all need to support this basic requirement (Humphrey and Sneath 1999; Niamir-Fuller 1999). Yet national governments around the world continue directly to curtail mobility through the alienation of land for agriculture, private ranches, environmental conservation and game parks, demarcation of new political boundaries, the establishment of fixed and ethnically based grazing areas, and physical inducements to settle, including the mechanization of water wells, creation of famine-relief centers, and concentrating police security in towns (Fratkin 1997). Moreover, governments have displaced local authority over range and water use, 
undermined the effectiveness of customary sanctions, and facilitated manipulation of development outcomes by the wealthy and influential (Little and Brokensha 1988; Little 1987).

We focus on two examples, the Maasai of Kenya and Tanzania, and Khalkh Mongols and other pastoralists of Mongolia, describing their recent histories and experiences with development and social change. While representing two of the world's major pastoral peoples, these examples were selected for comparison to illustrate the significance of the broader political-economic and historical context for the longrun sustainability of pastoral livelihoods. Both authors have carried out extensive fieldwork in these locations. Fratkin is a cultural anthropologist who has studied pastoral ecology, health and nutrition, and social change among Rendille, Ariaal, and Maasai of Kenya (Fratkin 1986, 1998, 2001; Fratkin and Roth 1990). Between 1994 and 1997, he was principal investigator of a National Science Foundation project investigating the social, health, and economic costs of pastoral sedentarization in Marsabit District, Kenya (Fratkin, Roth, and Nathan 1999a, 1999b). Mearns is a geographer who has studied the changes in pastoral livelihoods in Mongolia brought about by agricultural decollectivization since 1990. He was principal investigator for a MacArthur Foundation-sponsored, collaborative research project addressing these themes between 1991 and 1994 (Swift and Mearns 1993; Mearns 1993, 1996). During 1990-1997 Mearns also worked as a technical adviser to Government of Mongolia and various bilateral and multilateral agencies, and since 1999 he has been responsible for managing the World Bank's support for rural development in Mongolia.

\section{The Maasai of East Africa}

The Maasai are cattle and small stock (goats and sheep) herders occupying the savanna grasslands of southern Kenya and northern Tanzania. Never a single political entity, the Maasai, who today number about 350,000 in Kenya and 200,000 in Tanzania, are composed of a dozen independent groups including the Kisongo of Tanzania, and the Purko, Loita, Matapato, and Kaputei of Kenya. The Maasai politically dominated their agricultural neighbors in the 19th century (cf. Waller 1985), but this situation was reversed both during colonial and postindependence rule when African governments, made up of peoples from more populous agricultural communities, displayed little sympathy for pastoralist concerns. In Kenya today the Maasai are 350,000 in a population of 30 million, in Tanzania they are less than 200,000 in a population of 35 million, and thus constitute the status of a minority indigenous people.

Through treaties in 1904 and 1911, Kenyan Maasai lost 60 percent of their lands to British settlers and were confined to the unproductive regions south of the Kenyan railroad in present-day Kajiado and Narok Districts. Under colonial rule (1900-1963), Maasai were prohibited from selling livestock in settler-dominated markets, just as African farmers were prohibited from growing cash crops including tea and coffee.
The Maasai were subsequently restricted from grazing their cattle on former lands converted to national game reserves created by the British, including the Serengeti Park and Ngorongoro Crater in Tanzania in 1954, and the Nairobi, Amboseli, Tsavo, Masai Mara, and Samburu National Parks in Kenya (1948-1964) (Homewood and Rodgers 1991). Following Kenyan independence in 1963, the Maasai laced competition for land with Kikuyu and Kamba farmers moving off the highlands as their populations increased. Kajiado District's population grew from 22,000 (1948) to 86,000 (1969) to $149,000(1979)$ to 250,000 (1989), yielding an average annual growth of 3.5 percent. While some of this growth reflects natural increase among Maasai, most is due to migration by non-Maasai farmers onto Maasai lands. In 1962, the Maasai constituted 78 percent of Kajiado District's population; by 1992 they were less than half. Much of this land has been leased, rented, or sold outright by Malasai owners, who can no longer graze their animals on their former lands (Campbell 1993).

During the 1960s and 1970s, Western aid and international development agencies initiated programs in East African countries to improve livestock production and facilitate market integration of pastoralists. Local governments were encouraged to curtail pastoral herding on communally held lands and promote private ranching of beef and dairy resources, under the assumption that private landowners were better managers of their resources.

The ability of Maasai to transfer land individually is a recent phenomenon. In traditional Maasai society, no individual "owned" grazing or water resources; rather all members of the oloshon (territorial section) shared land and water in a given area. Following independence, the Kenyan government began to allocate individual sections of land (usually that with the best pasture and permanent water) to influential members of the community. It was believed that individual ranches would better contribute to the national livestock market than communal pastoralism and would set an example for other Maasai. But few Maasai benefited from the early privatization, nor did they keep their animals from grazing on the private ranches. In 1968, with support from USAID and the World Bank, Kenya proposed "group ranches" which conferred formal and legal land tenure to a community of coresidents. The Maasai in general accepted the group ranch concept as a way to prevent continuing agricultural encroachment on their land and to acquire legal tenure, enabling them to qualify for loans and the development of bore holes and cattle dips. In the 1980s, again with encouragement from the World Bank and its structural adjustment programs, Kenya titled much of the common land in the semiarid regions to individual owners, usually in 5-10 hectare plots for smallholders growing maize and other market crops. There has been a virtual stampede for land claims, especially in the Maasai areas of Kajiado and Narok Districts, as farmers as well as Maasai themselves rush to claim title to some land, lest they lose it all. The process of privatizing land in individual hands has led to permanent loss of 
common grazing lands through sales to non-Maasai and commercial ventures (Galaty 1992, 1994).

In Tanzania, more severe policies were carried out under the socialist policy of ujamaa (villagization), where Maasai engangs (homestcads) were burned, cattle confiscated, and populations forced into "livestock villages" controlling grazing and water resources (Hodgson 2001). Between 1969 and 1979, USAID and World Bank funded the Maasai Livestock and Range Management Project, whose $\$ 23$ million budget created cattle dips, dams, wells, and roads designed to increase livestock productivity and encourage the Maasai to sell more animals and beef. The project did not result in any substantial increase in livestock sales, at least not in Tanzania, although livestock were smuggled into Kenya for higher prices. As in Kenya, the water and road development contributed to the large numbers of immigrant farmers. Forced onto marginal lands or concentrated near the bore holes, pastures quickly became overgrazed. Predicting disaster, USAID finally terminated the project in 1979. Although USAID blamed the Maasai for their unwillingness to participate in either the implementation or maintenance of the project components, the Maasai on their part were satisfied with their improved access to water, veterinary dips, and ranching associations, but not the influx of farmers on their land (Hodgson 1999; Homewood 1995).

Because of their high savanna productivity, suitable for grain agriculture, pastoral lands in southern Kenya and notthern Tanzania have been targets for large-scale commercial ranch and farm enterprises. In Narok District, Kenya, hundreds of thousands of hectares have been sold to land speculators and farmers since 1980, and the rich and arable land of the Mau Escarpment is now producing commercial wheat and barley. More recently, Maasai in Kajiado District have seen water from Mt. Kilimanjaro diverted to commercial greenhouses growing flowers for the European market (Fratkin and Wu 1997).

In addition to losing land to ranchers and farmers, pastoralists have seen their mobility drastically reduced by the expansion of national game parks. Tourist revenues now account for 45 percent of Kenya's gross domestic product (GDP) and 30 percent of Tanzania's. The influence of international conservation groups rivals that of major corporations and international donors in government influence. $\mathrm{Na}$ tional governments and their international consultants from environmental groups, following Hardin's tragedy-of-thecommons thesis, blamed domestic cattle for overgrazing and reducing wildlife populations, and Maasai and other herders have been banned from most game parks. In 1959 in Tanzania (then British-ruled Tanganyika), Maasai agreed to abandon the rich plains of the Serengeti National Park (14,760 square kilometers) in exchange for grazing privileges on the external slopes of the Ngorongoro Conservation Area (NCA) $(8,292$ square kilometers). But they were prohibited from practicing any cultivation in the NCA between 1975 and 1992 because of concerns from environmental groups that cultivation diminished resource access for endangered species such as Black Rhinos (Shivji and Kapinga 1998).
Without cultivation, Maasai in the NCA suffered higher levels of malnutrition, particularly in children (severe malnutrition is defined as those children reaching less than $60 \%$ of WHO standard mean of weight for height). When the ban on cultivation was lifted in 1992, however, severe child malnutrition dropped from 19 percent in 1989 to 3 percent in 1995 (McCabe, this volume). Today, the Maasai depend on cultivation to supplement foods acquired from livestock, and without cultivating some maize, the Maasai will not be able to survive in the Ngorongoro Conservation Area (McCabe, Perkin, and Schofield 1992). Clearly, for many Maasai, cultivation has played an increasingly important role in subsistence and nutrition.

In addition to raising crops, Maasai have increasingly shifted their economy from subsistence pastoral production (producing mainly milk for household consumption) to commercial production (becf and dairy products for sale both to domestic and export markets). The sale of livestock is not new to pastoralists. Tanzanian Maasai were trading livestock for grain with neighboring Arusha in the mid-19th century (Spear 1997), and Maasai have typically sold 8-10 percent of their cattle to purchase grains and other commodities since the 1930s (Zaal and Dietz 1999). However, both demands and opportunities for market sales of livestock (particularly for beef to feed growing urban populations) have increased substantially in the past 25 years. "Caloric terms of trade" (CtoT) have declined in recent years with increasing maize prices, due to structural adjustment policies ending price supports. Today, one steer exchanged on the market can bring in 4-6 times the caloric worth of maize in drought years and 817 times the amount in wet years (i.e., a steer with a consumable weight of 100 kilograms yielding 230,000 kilocalories sells for $8,000 \mathrm{~K}$. sh. (70 K sh $/ \$ 1.00)$, buying approximately 800 kilograms of maize yielding 2,300,000 kilocalories). Milk enjoys a similar 6-10 advantage to maize in CToT (Zaal and Dietz 1999).

While increased commoditization of the livestock economy has benefited some Maasai, particularly wealthier herd owners or those with titled ranches, it has also led to a growing polarization of pastoralists into haves and have-nots. Zaal and Dietz (1999) report that in the Ol Karkar group ranch in Kajiado District, the top third of households owned over 35 total livestock units (TLUs) per person, mostly in cattle, while the bottom third had less than 7 TLUs, mostly in small stock of goats and sheep. While those households with large livestock herds logically remain committed to the pastoral economy, poorer Maasai often work for wealthier kinsmen, adopt agriculture, or migrate to towns in search of low-paying jobs such as watchmen, or for women, as maids or prostitutes (Fratkin 2001; Talle 1988).

The Maasai are rapidly transforming from seminomadic subsistence pastoralists to agropastoralists, ranchers, and urban workers, whose wealth differentials from rich to poor resemble the larger national picture of both extremes. The ability of most Maasai to achieve self-sufficiency through livestock production alone is lost, mainly because their land 
has been demarcated, divided, individuated, and reduced. In response, Maasai have taken up maize farming in increasing numbers. Sustainability for the Maasai now means having access to agricultural as well as pastoral resources. Because of their loss of lands, the Maasai situation may be more extreme than pastoralists living in other less-populated and more arid regions, such as northern Kenya. Here, pastoral peoples (including Rendille, Samburu, Turkana, Pokot, Gabra, Boran, Somalis) face other problems, however, particularly of armed violence and livestock raiding caused by a combination of drought, access to guns, and less police security (Fratkin 2001; Hendrickson, Armon, and Mearns 1998). For pastoral groups in these more arid regions where agriculture is more difficult and population densities are lower, the trend toward individuation of land rights and commoditization of the pastoral economy is slower, but also shows signs of developing (Fratkin 1998; Little et al. 2001).

\section{The Mongolia Case}

A quite different situation faces pastoralists of Mongolia. Following the collapse of the Soviet bloc in the early 1990s, the dismantling of the pastoral collectives and the privatization of formerly state-owned livestock, coupled with severe economic hardship for those unable to benefit from new economic opportunities, led to a dramatic reassertion of the importance of pastoralism within the Mongolian economy. Hybrid institutional forms have emerged that testify to the strong resilience of customary institutions repressed under agricultural collectivization during the previous four decades. In marked contrast to the African situation, Mongolian pastoralists continue to herd their animals on common pastures and enjoy constitutional protection of their land rights, supported by an evolving legal and institutional framework. However, a number of trends within and outside the pastoral livestock sector have combined to reduce livestock mobility, with the net result that future sustainability is by no means assured.

Mongolia is a vast ( 1.6 million square kilometers) but sparsely populated country of 2.4 million people owning around 26 million animals. Its diverse landscapes of mountains, steppes, and cold deserts have supported pastoral livelihoods for millennia, based on the movement of domestic cattle, yak, horses, camels, sheep, and goats between seasonal pastures according to various regionally specific patterns (Mearns 1993). Under Soviet-influenced economic planning and heavy direct subsidies from the Soviet Union since the 1920s, investments in urban-industrial development led to a steady decline in the share of population employed in the pastoral livestock sector. By the late 1980s, herders made up less than 20 percent of the population, but livestock production and processing industries remained the backbone of the national economy, accounting for over half of GDP and 40 percent of all exports, as well as the principal source of domestic food security. Although the pastoral livestock sector had been relatively neglected and was treated as a handmaiden to more "modern" sectors of the economy for decades, its importance was always recognized by successive communist governments. By the 1980)s Mongolia had developed policies more or less unique in the world to provide health and education services to nomadic herders and achieved virtually universal literacy.

Following a disastrous attempt at forced collectivization in 1929-1931, which was quickly abandoned, herders were encouraged to join voluntarily and contribute their livestock to pastoral collectives (negdel) in the 1950s, by means of a combination of punitive taxes on private livestock holdings and policies favoring the pooling of funds to bore wells, buy haymaking equipment, and build winter shelters for animals. By 1959 virtually all of Mongolia's herding houscholds were members of collectives. The collectives provided transport for nomadic moves between seasonal pastures, supplementary feed for the harsh winter and spring, cleared snow from pastures, and provided veterinary and specialized animal breeding services (Humphrey 1978; Mcarns 1996).

Following the collapse of the Soviet Union in 1991, Mongolia underwent radical economic and political reform. The state retreated from direct involvement in production, and prices were freed from previous controls. Agricultural collectives were transformed into joint-stock companies, most of which quickly fragmented into private partnerships, companies, and individual houschold enterprises. Many former employees of bloated or newly defunct state burcalucracies and enterprises acquired livestock under the national program to privatize state assets and moved back to the countryside to join their pastoral relatives. In 1990 state colleclives owned 68 percent of all livestock; by 1994,90 percent of the animals were privately owned (Mearns 1996), and virtually all are now in private hands. For want of alternative employment opportunities, the pastoral livestock sector acted as the social safety net of last resort throughout the carly period of economic transition, and the number of herding families more than doubled to around 35 percent of the total population by the mid-1990s.

The early 1990 s saw a reemergence and a strengthening of khot ails, customary groups of around two to ten cooperating households that form the basic social unit in Mongolian pastoral society, but which the state attempted to repress under collectivization. Normally made up of consanguineal or affinal kin, the khot ail acts in part as a social safety net for poorer households, providing forms of mutual assistance and pooling risk betwcen households, including sharing food resources as well as long-term loans of livestock. Aggregated into larger communities by virtue of shared use of common seasonal pastures, khot ails are a forum within which several overlapping forms of collective action take place, including a certain amount of coordination in the use of pastureland according to locally evolved norms and customs (Mearns 1996; Fernandez-Gimenez 1997).

While pastoral production is firmly back in the hands of independent households, pastureland is constitutionally excluded from private ownership. Of Mongolia's total land area, 80 percent is under pasture, making up possibly the largest 
contiguous area of common grazing in the world. A land law developed in 1995 set out a broad framework for guaranteeing seasonal pasture rotation according to locally specific pat terns of customary land tenure (PALD 1993; Mearns and Swift 1995; Hanstad and Duncan 2001). The land law was revised in 2002, in part to permit transferable possession rights over certain types of land, such as arable land used for urban and periurban housing, but the principle of public ownership of pastureland remains unchallenged. It is this continued public ownership of pastureland, combined with private ownership of livestock, that distinguishes Mongolia from other pastoralist regimes, particularly in Africa and the Middle East.

Several problems associated with rapid decollectivization in Mongolia were foreseen during the early 1990s, including increased wealth differentiation between herding households and the inability of poor khot ails to support all members (Swift and Mearns 1993). For example, Cooper (1993) warned that while customary institutions appeared initially to be supporting weaker members, wage-labor relationships between richer and poorer households could well develop in the near future with adverse consequences for the poor. Templer, Swift, and Payne (1993) argued that without some continued provision of a safety net by the state, environmental risks would be likely to increase for poor households. While there was an initial increase in livestock marketing and offtake following the 1991 liberalization (Edström 1993), subsequent offtake declined substantially, as herders preferred to hold assets in the form of livestock in an inflationary economy. Between 1993 and 1999, total livestock numbers rose steadily from around 25 million to over 33 million head. Three consecutive years of drought and $d z u d$ (extremely severe winter weather) over 1999-2002 sharply reduced livestock numbers to historical levels of around 25 million head, with the heaviest costs being borne by poorer, often newcomers to herding.

By the late 1990s, several new threats to the sustainability of pastoral livelihoods emerged in addition to those that were foreseen earlier in the decade, all of which are manifested in declining livestock mobility (Agriteam-Canada 1997; NSO and World Bank 2001). Rapidly rising inequality in asset holdings between richer and poorer herding households has led to a divergence of interests between rich and poor and has weakened the observance of norms and customs regarding pasture use. Competition for grazing land has reached endemic proportions in the more accessible and higher-potential central steppes, and herders are reluctant to leave their winterspring camps where they are able to guard those most valued of seasonal pastures. More powerful extended families are better able to "capture" pastures by maintaining camps in several locations at once, while asset- and labor-poor households are squeezed out and forced to join khot ails of richer herders as wage laborers. Many other herding families who would otherwise move to more distant pastures prefer to camp close to district centers, as these are the only potential source of essential trade commodities and access to the few social services that remain economically viable.
In addition to these internal pressures within the pastoral livestock sector itself, the legislative, institutional, and policy environment of which the Mongolian government could be justly proud also shows signs of becoming less than favorable towards pastoralists (Agriteam-Canada 1997). Since the early 1990 s, the political economy of land tenure reform has tended on balance to favor those of diverse political hues who have strongly argued against the privatization of pastureland, often for very different reasons (e.g., to prevent Chinese control over Mongolian territory). By the late 1990s, the cumulative, adverse impact of inappropriate technical advice from donor organizations was discernible. For example, the rift between ministries of agriculture and environment, always divided along production-orientated versus protectionorientated lines, was becoming ever wider under advice from Western environmentalists and those pressing for cadastral surveys and titling of individualized land parcels. And there were pressures to increase the share of Mongolian territory under protected areas from less than 15 percent to 30 percent.

Much work still needs to be done on the institutional, legislative, and policy framework for pastoral livestock production in Mongolia, but the shape of an appropriate strategy has been emerging for some time (NSO and World Bank 2001; Government of Mongolia 2002). At its core, such a strategy must rely on ensuring continued livestock mobility between seasonal pastures, if not necessarily mobility of all livestock herders themselves. Land tenure policy is important, but it is neither possible nor desirable to attempt to legislate for all potential outcomes (Bruce and Mearns 2002). Much more important is to provide for robust, decentralized mechanisms whereby herders themselves, perhaps organized into grazing associations of their own devising, decide on and enforce local grazing management schemes. They will require support from the state and civil society institutions in conflict mediation and resolution. Access to credit and investment in rural infrastructure should build on the essential need to maintain livestock mobility, for example in assisting voluntarily formed herder groups to purchase trucks. Donor assistance will help to move this agenda forward, but only if it offers options based on lessons from international experience from among which Mongolia's herders and policy makers can make informed choices, rather than offering a blueprint that must be adopted.

\section{Is Sustainable Development a Contradiction in Terms?}

After more than a decade of earnest but unsuccessful application, the concept of sustainable development seems to be losing ground among its two strongest advocates: the international lending community and bilateral donors on the one hand, and environmental interest groups and ecologists on the other (Dovers and Handmer 1993; Lele 1991). Is sustainable development a contradiction in terms; an ideal state made impossible by the seemingly irreducible threat of expanding populations on one hand and the insatiable appetite 
of the global economy on the other? The signal failure to promote more equitable patterns of growth or even to conserve existing resources, let alone to limit growth, is found not only in the world's heavily populated agricultural and urban regions, but also in its furthest reaches.

This is unfortunate, as pastoralists have less ability to sustain their livelihoods now than at any time in their past. Following a seven-year project among Boran of southern Ethiopia, the International Livestock Center for Africa (ILCA) concluded that human populations were growing faster than their livestock, whose reproductive and dairy productivity were declining due to increasing competition for forage. In the absence of any development intervention, ILCA predicted that the Boran would face increasing food energy deficits, leading in turn to permanent and expanding efforts to cultivate, to an irreversible offtake of cattle to buy grain, to increased out-migration of young men leading to key labor shortages, to increased wealth stratification, and ultimately to a growing population of periurban poor dependent on wage labor to survive (Coppock 1994).

Increasing population pressure and competition for land leads to several solutions. One view, articulated in the environmental journal Ambio, recommends abandoning pastoralism altogether and encouraging former herders to plant forage crops, cereals, and fodder to raise livestock in sedentary settings and to integrate into an industrialized, market-based economy (Steen 1994). An opposing view emphasizes restoring or protecting pastoralism through statutory legal recognition of customary rights to water and pasture resources; rights-of-way for herds to travel through cultivated lands during migration periods; rights to unhindered passage across international borders; recognition of pastoralist knowledge of water, pasture, and herd management; an end to propaganda to sedentarize pastoralists; the right to fair prices and water; and, finally, the right to run their own local affairs (Baxter 1993; Fratkin 1998). A middle position, reinforced by the Mongolian and East African examples, is the increased market integration and commoditization of livestock based on hybrid forms of ranching and more traditional pastoral herding strategies, as well as the creation of deeper ties with farming and urban communities.

For pastoral populations to continue to be able to live off their herds, several changes in development policy must occur. They will necessarily take different forms in different places, shaped by particular historical and political-economic contexts, but taken together these changes would go a long way toward resolving the challenge of sustainability of pastoral livelihoods. First and foremost, herders must have rights to pasture and water, rights which may include communal, village-based, or cooperative tenure guaranteed by law. Mongolia's success in revitalizing its livestock system is due not just to the individual privatization of herds, but to national policies guaranteeing shared grazing resources, access to markets, and access to veterinary care, fragile though past successes along these lines now appear to be. Conversely, the greatest impediment to Maasai pastoralism in Africa is the enclosure, privatization, and fencing of grazing lands which exclude former owners from their traditional lands. Recognition of customary land tenure is essential to the continuation of pastoralism in most parts of the world.

Second, the international development community needs to recognize that pastoral livestock management in arid lands is productive, rational, and an essential way of utilizing scarce and patchy resources. Pastoral strategies of herd diversity, pastoral mobility, and residential flexibility offer a means to convert patchy, seasonal, and scarce vegetation into calories and protein for human consumption in arid or marginal lands. Policies to support such strategies now need to be more eclectic than ever: Most important among them may be appropriate forms of conflict mediation and resolution, in Mongolia just as in northern Kenya (Mearns 1997b; Hendrickson, Armon, and Mearns 1998; Leach, Mearns, and Scoones 1999; Bruce and Mearns 2002). Devolution of decision-making power to herder groups at an appropriate scale also makes more sense than attempting to second-guess herder strategies. Rather than try to design once and for all the "perfect" land tenure policy ostensibly based on customary regimes, for example, it is far better to empower herder groups themselves to make and remake the rules as they go along, within appropriately prescribed limits.

Third, pastoral risk management ought to be supported through strategies and interventions to increase preparedness of herders and local authorities for drought and other climatic risks (e.g., severe winter weather in the Mongolia case). Recent work, particularly in Kenya under the World Banksupported Arid Lands Resource Management Project and in Mongolia under the World Bank-supported Sustainable Livelihoods Project, has identified promising approaches to drought preparedness, including community-based early warning systems, rapid destocking of livestock to protect pastoralists' purchasing power during droughts, communitybased water development (e.g., wells, rainwater harvesting using microcatchment dams), and the use of special or restricted areas (e.g., wildlife reserves, military training areas) for emergency grazing (Morton 2001). The use of credit-based schemes to reconstitute household herds following drought and other risk events has also been an arca in which encouraging developments have taken place in Kenya, Mongolia, and elsewhere. Other measures to support pastoral risk management are also receiving close attention, including the use of microfinance services (savings and loans, index-based insurance) to widen the range of options herders may pursue before, during, and after risk events, so as to reduce their dependence on external agencies. In addition, pastoral groups, including those in the arid north of Kenya such as Boran and Rendille, are also adopting maize agriculture where possible (Coppock 1994; Little et al. 2001; Smith 1999).

Fourth, pastoral populations should not be pitted against wildlife conservation, as is happening in Africa and elsewhere. Pastoral production is not necessarily harmful to wildlife conservation, but may instead be an important component of rangeland ecology. The eviction of pastoralists from game parks does not solve the problem of unsustainable range use, 
but creates even greater problems by forcing pastoralists into greater competition with agricultural or other pastoral populations. Wildlife policy needs to be coordinated with pastoral needs, preferably though direct meetings between governments and pastoralists and by mutual sharing of rewards such as tourism revenues (Mearns 1997a, 1997b).

Finally, pastoralists need better access to credit and savings institutions to improve animal husbandry, pay for school fees, purchase veterinary medicines, and improve water sources through low-cost dams and catchments. Pastoralism remains an important livelihood system in vast areas of the world. It has the potential to provide meat, leather, wool, and milk to growing towns and cities in the developing world, as well as to be part of the solution to conserving valued habitats and landscapes, and should be encouraged not discouraged by development planners and national governments.

\section{References Cited}

Agriteam-Canada

1997 Study of Extensive Livestock Production Systems in Mongolia. Final Report to Asian Development Bank. Calgary: Agriteam-Canada.

Barfield, Thomas J.

1993 The Nomadic Alternative. Englewood Cliffs, N.J.: Prentice Hall.

Baxter, Paul T.W.

1993 The "New" East African Pastoralism: An Overview. In Conflict and the Decline of Pastoralism in the Horn of Africa. J. Markakis, ed. Pp. 143-162. London: MacMillan.

Behnke, Roy H., Jr. 1994 Natural Resouree Management in Pastoral Africa. Development Policy Revicw 12:5-27.

Behnke, Roy H., Jr., Ian Scoones, and Carol Kerven, eds. 1993 Range Ecology at Disequilibrium: New Models of Natural Variability and Pastoral Adaptation in African Savannas. London: Overseals Development Institute.

Bromley, Danicl W, and Michael M. Cernea

1989 The Management of Common Property Natural Resources: Some Conceptual and Operational Fallacies. World Bank Discussion Papers 57. Washington, D.C.: World Bank.

Bruce, John, and Robin Mearns

2002 Natural Resource Management and Land Policy in Developing Countries: Lessons Leamed and New Challenges for the World Bank. London: International Institute for Enviromment and Development

Campbell, David $\mathrm{J}$.

1993 Land as Ours, Land as Mine: Economic, Political and Ecological Marginalization in Kajiado District. In Being Maasai: Ethnicity and Identily in East Africa. T. Spear and R. Waller, eds. Pp. 258-272. London: James Currey.

Cooper, Louise

1993 Patterns of Mutual Assistance in the Mongolian Pastoral Economy. Nomadic Peoples 33:153-162
Coppock, D. Layne

1994 The Borana Plateau of Southern Ethiopia: Synthesis of Pastoral Research, Devclopment and Change, 1980-91. Addis Ababa: International Livestock Centre for Africa.

Dahl, Gudrum, and Anders Hjort

1976 Having Herds: Pastoral Herd Growth and Houschold Economy. Stockholm Studies in Social Anthropology 2. Stockholm: University of Stockholm.

de Haan, Comelis, Tjaart Schillhorn van Veen, Brian Brandenburg, Jerome Gauthier, Francois Le Gall, Robin Mearns, and Michel Simeon

2001 Livestock Development: Implications for Rural Poverty, the Environment, and Global Food Security. Directions in Development Series. Washington, D.C.: World Bank.

Dyson-Hudson, Rada, and J. Terrance McCabe

1985 South Turkana Nomadism: Coping with an Unpredictably Varying Environment. Ethnography Series FL. 17-001, Human Relations Area Files. New Haven, Conn.: HRAFlex Books.

Dovers, Stephen R., and John W. Handmer

1993 Contradictions in Sustainability. Environmental Conservation 20:217-222.

Edström, Jerker

1993 The Reform of Livestock Marketing in Mongolia: Problems for a Food Secure and Equitable Market Development. Nomadic Peoples 33:137-152.

Fernandez-Gimenez, Maria E.

1997 Landscapes, Livestock and Livelihoods: Social, Ecological, and Land Use Change Among the Nomadic Pastoralists of Mongolia. Ph.D. dissertation, University of California, Berkeley.

Food and Agriculture Organization (FAO)

1994 Food Supply Situation and Crop Prospects in Sub-Saharan Africa. Rome: FAO.

Fratkin, Elliot

1986 Stability and Resilience in East African Pastoralism: The Arialal and Rendille of Northern Kenya. Human Ecology 14:269-286.

1997 Pastoralism: Governance and Development Issues. Annual Review of Anthropology 26:235-261.

1998 Ariaal Pastoralists of Northern Kenya: Surviving Drought and Development in Africa's Arid Lands. Cultural Survival Studies in Ethnicity and Change. Needham Heights, Mass: Allyn and Bacon.

2001 East African Pastoralism in Transition: Maasai, Boran, and Rendille Cases. African Studies Review 44:1-25.

Fratkin, Elliot, and Eric A. Roth

1990 Drought and Economic Differentiation Among Arial Pastoralists of Kenya. Human Ecology 18:385-402.

Fratkin, Elliot, Eric A. Roth, and M. A. Nathan

1999a Health Consequences of Pastoral Sedentarization Among Rendille of Northern Kenya. In The Poor are Not Us: Poverty and Pastoralism. David M. Anderson and Vigdis Broch-Due, eds. Pp. 149-163. Oxford: James Currey.

1999 b When Nomads Settle: The Effects of Commoditization, Nutritional Change, and Formal Education Among Ariaal and Rendille Pastoralists of Kenya. Current Anthropology 40:729735. 
Fratkin, Elliot, and Tiffany Sher-Mei Wu

1997 Maasai and Barabaig Pastoralists Struggle for Land Rights in Kenya and Tanzania. Cultural Survival Quarterly 21(3):5561 .

Galaty, John G.

1992 "This Land is Yours": Social and Economic Factors in the Privatization, Subdivision and Sale of Maasai Ranches. Nomadic Peoples 30:26-40.

1994 Rangeland Tenure and Pastoralism in Africa. In African Pastoralist Systems. Elliot Fratkin, Kathleen Galvin, and Eric A. Roth, eds. Pp. 185-204. Boulder, Colo.: Lynne Rienner.

Gilles, Jerre L., and Cornelis de Haan

1994 Recent Trends in World Bank Pastoral Development Projects: A Review of 13 Bank Projects in Light of the "New Pastoral Ecology." Pastoral Development Network Papers 36b. London: Overseas Development Institute.

Grovernment of Mongolia

2002 Rural Development Strategy (Draft). Ulaanbaatar: Center for Policy Research for Government of Mongolia.

Hanstad, Timothy, and Jennifer Duncan

2001 Land Reform in Mongolia: Observations and Recommendations. Rural Development Institute Reports on Foreign Aid and Development 109. Seattle: Rural Development Institutc.

Hardin, Garrett

1968 The Tragedy of the Commons. Science 162:1243-1248.

Hendrickson, Dylan, Jeremy Armon, and Robin Mearns 1998 The Changing Nature of Conflict and Famine Vulnerability: The Case of Livestock Raiding in Turkana District, Kenya. Disasters 22:185-199.

Hodgson, Dorothy L.

1999 Images and Interventions: The Problems of Pastoralist Development. In "The Poor Are Not Us": Poverty And Pastoralism in East Africa. David M. Anderson and Vigdis BrochDue, eds. Pp. 221-239. Oxford: James Currey.

2001 Once Intrepid Warriors: Gender, Ethnicity, and the Cultural Politics of Maasai Development. Bloomington: Indiana University Press.

Homewood, Katherine M.

1995 Development, Demarcation and Ecological Outcomes in Maasailand. Africa 65:331-350.

Homewood, Katherine M, and William A. Rodgers

1991 Maasailand Ecology: Pastoralist Development and Wildlife Conservation in Ngorongoro, Tanzania. Cambridge: Cambridge University Press.

Humphrey, Caroline

1978 Pastoral Nomadism in Mongolia: The Role of Herdsmen's Cooperatives in the National Economy. Development and Change 9:133-160.

Humphrey, Caroline, and David Sneath

1999 The End of Nomadism? Society, State, and the Environment in Inner Asia. Durham, N.C.: Duke University Press.

James, Valentine U

1996 Sustainable Development and Third World Countries. Westport, Conn.: Praeger.
Lamprey, Hugh F.

1976 The UNEP-MAB Integrated Project in Arid Lands: Phase III Kenya 1977-1980. Regional Project Document FP/II01-77. Nairobi: United Nations Environment Programme.

Leach, Melissa, and Robin Mearns, eds.

1996 The Lie of the Land: Challenging Received Wisdom on the African Environment. Oxford: James Currey.

Leach, Melissa, Robin Mearns, and Ian Scoones

1999 Environmental Entitlements: Dynamics and Instifutions in Community-Based Natural Resource Management. World Development 27:225-247

Lele, Sharachchandra M.

1991 Sustainable Development: A Critical View. World Development 19:607-621.

Little, Peter D.

1987 Land Use Conflicts in the Agricultural/Pastoral Borderlands: The Case of Kenya. $I n$ Lands at Risk in the Third World: Local Level Perspectives. Peter D. Little and Michael M. Horowil. eds. Pp. 195-211. Boulder, Colo.: Westview Press.

1994 The Social Context of Land Degradation ("Desertification") in Dry Regions. In Population and Environment: Rethinking the Debate. L. Arizpe, M. P. Stone, and D. C. Maijor, cds. Pp. 209251. Boulder, Colo.: Westview Press.

Little, Peter D., and David W. Brokensha

1988 Introduction: Anthropology, Development and Clange in East Africa. In Anthropology, Development and Change in Easi Alrica David W. Brokensha and Peter D. Little, eds. Pp. 1-12. Boulder, Colo.: Westview Press.

Little, Peter D., Kevin Smith, Barbara A. Cellarius, D. Layne Coppock, and Christopher B. Barrett

2001 Avoiding Disaster: Diversification and Risk Management Among East African Herders. Development and Change 32:401 433

McCabe, J. Terrance, Scott Perkin, and Claire Schofield

1992 Can Conservation and Development be Coupled Among Pastoral People? An Exanination of the Maasal of the Ngorongoro Conservation Area, Tanzania. Human Organization $51: 353-366$

Meams, Robin

1993 Territoriality and Land Tenure Among Mongolia Pastoralists: Variability, Continuity and Change. Nomadic Pcoples 33:73-103.

1996 Community, Collective Action and Common Graking: The Case of Post-Socialist Mongolia. Journal of Development Studies $32: 297-339$

1997 a Livestock and Environment: Potential for Complementarity. World Animal Review 88:2-14.

$1997 \mathrm{~b}$ Balancing Livestock Production and Environmental Goals. World Animal Review 89:24-33.

Mearns, Robin, and Jeremy Swift

1995 Pastureland Tenure and Management in the Retroat from a Centrally Planned Economy in Mongolia. In Procecdings of the Fifth International Rangelands Conlerence, Salt Lake City, Ulah N. West, ed. Pp. 96-98. Denver, Colo.: Socicty for Range Management. 
Morton, John, ed.

2001 Pastoralism, Drought, and Planning: Lessons from Northern Kenya and Elsewhere. Chatham, U.K.: Natural Resources Institute.

Niamir-Fuller, Maryam, ed.

1999 Managing Mobility in African Rangelands: The Legitimization of Transhumance. London: IT Publications.

National Statistical Office (NSO) and World Bank

2001 Mongolia Participatory Living Standards Assessment 2000. Ulaanbaitar, Mongolia: National Statistical Office and World Bank.

Ostrom, Elinor

1990 Governing the Commons: The Evolution of Institutions for Collective Action. Cambridge: Cambridge University Press.

Policy Alternatives for Livestock Development (in Mongolia) (PALD) 1993 Options for the Reform of Grazing Land Tenure in Mongolia. PALD Policy Options Papers 1. Brighton, U.K.: Institute of Development Studies, University of Sussex.

Peters, Pauline E.

1994 Dividing the Commons: Polities, Policy and Culture in Botswanil. Charlottesville: University Press of Virginia

Pratt, David J., Francois Le Gall, and Cornelis de Haan

1997 Investing in Pastoralism: Sustainable Natural Resource Use in Arid Africa and the Middle East. World Bank Technical Papers 365. Washington, D.C.: World Bank.

Roe, Emery, Lynn Huntsinger, and Keith Labnow

1998 High Reliability Pastoralism. Journal of Arid Environments $39: 39-55$.

Sandford, Stcphen

1983 Management of Pastoral Development in the Third World. Chichester, U.K.: Wiley.

Scoones, lan, ed.

1995 Living with Uncertainly: New Directions for Pastoral Development in Africa. London: IT Publications.

Serageldin, Ismail

1996 Sustainability and the Wealth of Nations: First Steps in an Ongoing Journey. Environmentally Sustainable Development Studies and Monographs Series 5. Washington, D.C.: World Bank.

Shivji, Issa G., and Wilbert B. Kapinga

1998 Matsai Rights in Ngorongoro, Tanzania. London: International Institute for Environment and Development.

Simpson, J. R., and P. Evangelou, eds.

1984 Livestock Development in Sub-Saharan Africa: Constraints, Prospects, Policy. Boulder, Colo.: Westview Press.

Smith, Kevin

1999 The Farming Alternative: Changing Age and Gender Roles Among Sedentarized Rendille and Ariaal. Nomadic Peoples $3: 131-146$.
Spear, Thomas

1997 Mounlain Farmers: Moral Economies of Land and Agricultural Development in Arusha and Meru. Oxford: James Currcy.

Steen, E.

1994 Drylands of the Third World: Potential for Future Development. Ambio 23: 4.58-460.

Swallow, Brent

1994 The Role of Mobility Within Risk Management Strategies of Pastoralists and Agropastoralists. SAP Gatekeeper Series 47. London: International Institute for Environment and Development (IIED).

Swift, Jeremy

1991 Local Customary Institutions as the Basis for Natural Resource Management Among Boran Pastoralists in Northern Kenya. IDS Bulletin 22(4):34-37.

1996 Desertification: Narratives, Winners and Losers. In The Lie of the Land: Challenging Received Wisclom on the African Environment. Melissa Leach and Robin Mearns, eds. Pp. 73-90. Oxford: James Currey.

Swift, Jeremy, and Robin Mearns, eds.

1993 Pastoralism in Mongolia. Nomadic Pcoples 33:3-239.

Talle, Aud

1988 Women at a Loss: Changes in Maasai Pastoralism and their Effects on Gender Relations. Stockholm Studies in Social Anthropology 19. Stockholm; Department of Social Anthropology, University of Stockholm.

Templer, Guy, Jeremy Swift, and Polly Payne

1993 The Changing Significance of Risk in the Mongolian Pastoral Economy. Nonadic Peoples 33:105-122

United Nations Conference on Desertification (UNCOD)

1977 United Nations Conference on Desertification: Its Causes and Consequences. Nairobi: United Nations Environment Program (UNEP).

Waller, Richard

1985 Ecology, Migration and Expansion in East Africa. African Affairs 84:347-370.

World Bank

1997 Expanding the Measure of Wealth: Indicators of Environmentally Sustainable Development. Environmentally Sustainable Development Studies and Monographs Series 17. Washington, D.C.: World Bank.

2002 Making Sustainable Commitments: An Environment Strategy for the World Bank. Washington, D.C.: World Bank

2003 Sustainable Development in a Dynamic World: Transforming Institutions, Growth, and Quality of Life. World Development Report 2003. Washington, D.C.: World Bank

Zaal, Fred, and Ton Dict\%

1999 Of Markets, Maize, and Milk: Pastoral Commoditization in Kenya. In "The Poor are Not Us": Poverty and Pastoralism in East Africa. David M. Anderson and Vigdis Broch-Due, cds. Pp. 163-198. Oxford: James Currcy. 